\title{
Detection of anti-dsDNA as diagnostic tool
}

\author{
A. J. G. SWAAK, JANNY GROENWOLD, L. A. AARDEN, \\ AND T. E. W. FELTKAMP
}

From the Department for Autoimmune Diseases of the Central Laboratory of the Netherlands Red Cross Blood Transfusion Service, Laboratory for Experimental and Clinical Immunology, University of Amsterdam, and Department for Rheumatic Diseases, Slotervaart Hospital, Amsterdam, The Netherlands.

SUMMARY The diagnostic significance of anti-dsDNA determinations was evaluated in 2 different groups of patients. When the immunofluorescence technique (IFT) with Crithidia luciliae and the Farr assay with ${ }^{3} \mathrm{H}$-labelled-PM2 DNA were applied to a selected panel of 536 sera from patients with various well-defined autoimmune diseases, positive results were obtained only with serum samples from patients with systemic lupus erythematosus (SLE). On the other hand when we screened 4431 sera sent to our laboratory for diagnostic reasons, we observed a high incidence of antibodies to dsDNA in patients who did not fulfil the preliminary American Rheumatism Association's criteria for SLE and did not have the diagnosis SLE. Furthermore, a significant number of the positive sera showed peculiar behaviour in that they were positive only in the IFT on Crithidia luciliae and not in the Farr assay.

Early methods for detection of anti-DNA antibodies showed that the presence of these antibodies is strongly correlated with systemic lupus erythematosus (SLE). ${ }^{1}$ However with the development of more sensitive methods these antibodies were found to occur in numerous clinical syndromes. ${ }^{2-11}$

Subsequent experiments have shown that whenever reaction conditions are carefully controlled and the substrate DNA is checked for 'doublestrandedness', the presence of antibodies to dsDNA is restricted to patients with SLE. ${ }^{12-14}$

A comparative study organised by the Arthritis and Rheumatism Council for Research ${ }^{15}$ supported the notion that from a diagnostic point of view 2 assays are superior in terms of sensitivity and specificity, the Farr assay using well-defined radioactive dsDNA and the immunofluorescence technique (IFT) using the kinetoplast of Crithidia luciliae as a substrate. ${ }^{16}$ Although in this comparative study only some of the laboratories used the latter assay, its specificity has been amply confirmed in later papers. ${ }^{11} 17$

Most of the work on the specificity of antidsDNA assays has been carried out by testing panels of serum samples from selected patients

Accepted for publication 14 December 1979

Correspondence to Dr A. J. G. Swaak, Slotervaart Hospital, Department for Rheumatic Diseases, Louwesweg 6, Amsterdam, The Netherlands. with well-defined clinical manifestations. This procedure excludes the analysis of serum from those patients for which the use of the anti-dsDNA assay as a diagnostic tool is most relevant, that is, patients with SLE-like syndromes not meeting the actual diagnosis SLE. To include this group of patients in our study we changed the selection procedure in that we analysed the clinical features of those patients who were positive for anti-dsDNA on routine testing in our laboratory.

\section{Materials and methods}

SERA

The sera used for the analysis of the specificity of anti-dsDNA determinations were obtained from 135 healthy blood donors and from 525 patients with a variety of clinical conditions. The patients included 150 with classical rheumatoid arthritis (RA) fulfilling the American Rheumatism Association's (ARA) criteria, 17 with Sjögren's syndrome, 17 with scleroderma, 73 with an autoimmune liver disease (primary biliary cirrhosis, active chronic hepatitis, or cryptogenic cirrhosis with autoantibodies), 64 with myasthenia gravis, 72 with an autoimmune thyroiditis (thyrotoxicosis, Hashimoto's disease, or myxoedema), 51 with autoimmune gastritis (pernicious anaemia, antibodies to parietal cells with or without antibodies to intrinsic factor 
or vitamin $\mathbf{B}_{\mathbf{1 2}}$ deficiency). 36 with Addison's disease, 45 with autoimmune haemolytic anaemia, and 51 active SLE patients fulfilling the preliminary ARA criteria for SLE. ${ }^{18}$

Furthermore, we included in our study the sera of 4431 patients sent to our laboratory for routine anti-dsDNA determinations. When a serum was found to be positive, the clinician of the patient was contacted, and his clinical diagnosis of the patient was recorded together with the ARA criteria that were met. Sera were stored at $-20^{\circ} \mathrm{C}$.

\section{ANTI-dSDNA DETECTION ON CRITHIDIA \\ L UCILIAE}

Details of this immunofluorescence technique (IFT) have been published. ${ }^{19}$ Crithidia luciliae were grown, harvested, and used with one modification: the final suspension was not made in water but in an ovalbumin solution ( $1 \mathrm{~g} / \mathrm{l}$ distilled water). Sera were diluted 1:10 in phosphate-buffered saline (PBS, $0.01 \mathrm{M}$ phosphate, $0.14 \mathrm{M} \mathrm{NaCl}, \mathrm{pH} \mathrm{7.4)}$ ). Fluorescence of kinetoplasts was considered to indicate
anti-dsDNA activity. To facilitate the location of kinetoplasts, propidium iodide (Calbiochem, $1 \mathrm{~g} / \mathrm{l}$, lot no. 410154) was used as counterstain, with a KP-560 barrier filter to separate propidium iodide fluorescence from fluorescein isothiocyanate (FITC) fluorescence.

\section{ANTI-dSDNA DETERMINATION WITH THE \\ FARR ASSAY}

Details of the method have been published. ${ }^{16}$ 20-22 ${ }^{3} \mathrm{H}$-labelled PM2-DNA (100 ng) was incubated with $50 \mu \mathrm{l}$ serum in the presence of $800 \mu \mathrm{g}$ normal human gammaglobulin. The incubation volume was $0.2 \mathrm{ml}$ and the medium PBS. After incubation of the mixture for $1 \mathrm{~h}$ at $37^{\circ} \mathrm{C}, 5 \mathrm{ml}$ cold $50 \%$-saturated ammonium ${ }^{\circ}$ sulphate was added. The precipitate was allowed to form for $30 \mathrm{~min}$ at $4^{\circ} \mathrm{C}$ and was then centri- $\dot{0}$ fuged for $15 \mathrm{~min}$ at $3000 \mathrm{~g}$ in a refrigerated centrifuge, $\mathrm{O}$ washed twice with $50 \%$ saturated ammonium sulphate, and counted. The mean binding of 135 Tा control sera was $5^{\circ} \pm 3 \%$ (SD) of the input. Anti- 음 dsDNA activity is expressed in terms of units per

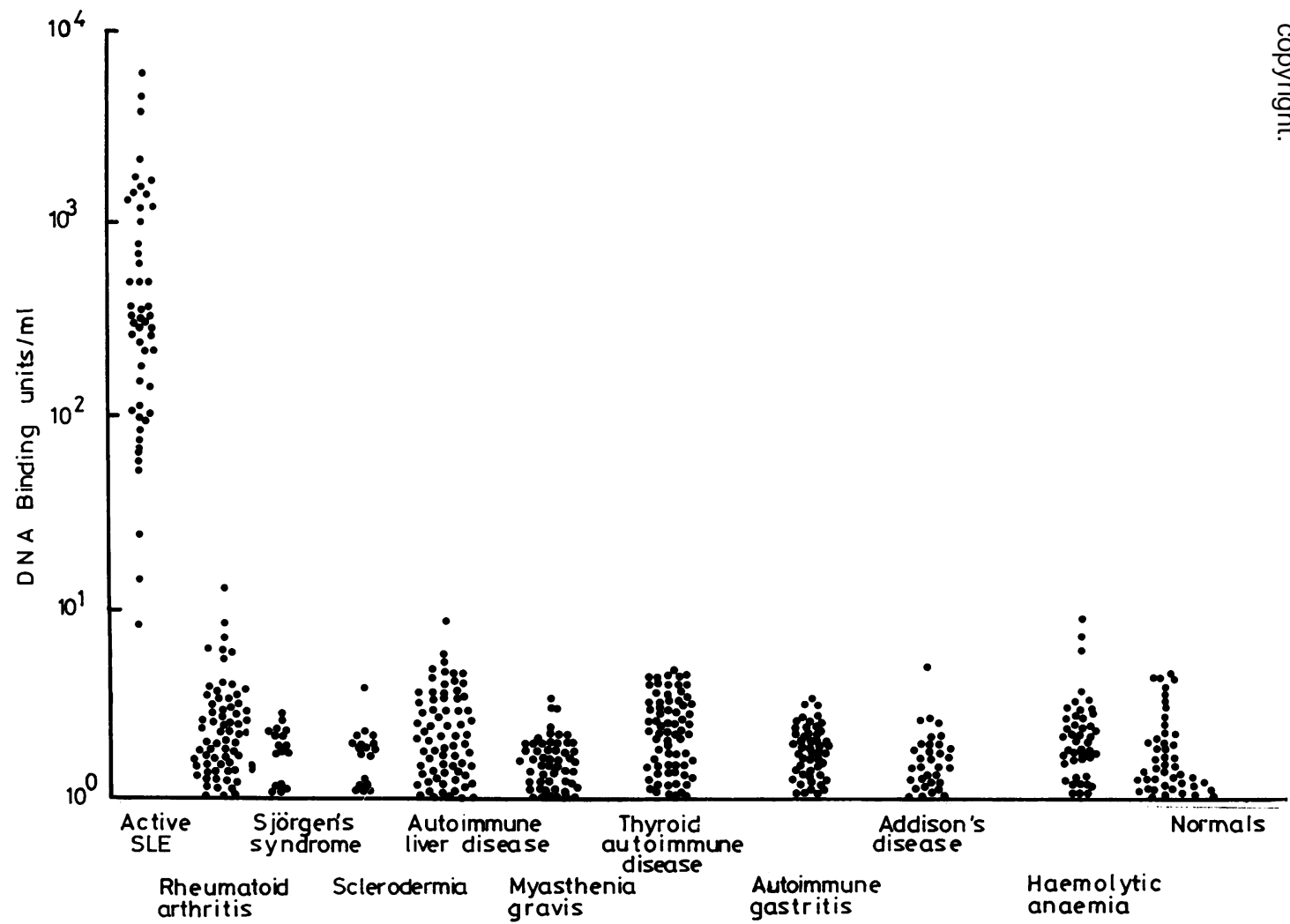

Fig. 1 Incidence of anti-dsDNA in sera of patients with various autoimmune diseases, as measured by the Farr assay. 
$\mathrm{ml}, 1$ unit being defined as the amount of antidsDNA precipitating $30 \%$ of the added DNA under the above conditions. ${ }^{22}$

\section{Results}

\section{SPECIFICITY OF ANTI-dSDNA ON SERUM} OF PATIENTS WITH WELL-DEFINED

A UTOIMMUNE DISEASE ENTITIES

When we analysed the serum of patients with defined clinical manifestations in the Farr assay and the IFT, we noticed a clear-cut specificity for SLE. Fig. 1 shows the dsDNA-binding values in the Farr assay of serum from patients with the indicated diagnosis. The IFT gave concordant results with 2 exceptions: 1 of the weakly positive SLE sera (20 $\mathrm{U} / \mathrm{ml}$ ) was negative in the IFT, and 1 patient with myasthenia gravis gave a weak kinetoplast fluorescence, while it was negative in the Farr assay.

\section{ANTI-dSDNA IN SERA SENT FOR \\ DIAGNOSTIC REASONS}

The sera sent to our laboratory for routine antidsDNA determinations were screened with the IFT. Of the 4431 sera tested 158 showed at least a minimally visible kinetoplast fluorescence. Sera that were positive in the IFT (including the weakly positive ones) were then tested in the Farr assay. Of these 158 only 80 were positive in the Farr assay. The clinical diagnosis SLE were made in 91 patients of the 158 IFT-positive and in 56 patients of the 80 Farr-positive groups. The preliminary ARA criteria were met in 53 of the 158 IFT-positive and in 37 of the 80 Farr-positive sera. These data are summarised in Table 1. When DNA-binding levels were included, we observed that the diagnosis SLE occurred more frequently in patients with high anti-dsDNA levels (Table 2).

Table 1 Anti-dsDNA in 4431 sera sent for routine analysis

\begin{tabular}{|c|c|c|c|c|c|}
\hline \multicolumn{2}{|c|}{$\begin{array}{l}\text { Number of positive } \\
\text { sera in: }\end{array}$} & \multicolumn{4}{|c|}{$\begin{array}{l}\text { Number of patients with: } \\
\text { diagnosis } S L E \geqslant \geqslant A R A \text { criteria }\end{array}$} \\
\hline $\begin{array}{l}\text { IFT } \\
\text { Farr assay }\end{array}$ & $\begin{array}{r}158 \\
80\end{array}$ & $\begin{array}{l}91 \\
56\end{array}$ & $\begin{array}{l}(57 \%) \\
(70 \%)\end{array}$ & $\begin{array}{l}53 \\
37\end{array}$ & $\begin{array}{l}(33 \%) \\
(46 \%)\end{array}$ \\
\hline
\end{tabular}

Table 2 Influence of anti-dsDNA level in the Farr assay

\begin{tabular}{lllll}
\hline $\begin{array}{l}\text { Anti-dsDNA } \\
\text { activity (units/ml) }\end{array}$ & $\begin{array}{l}\text { Number of } \\
\text { patients }\end{array}$ & $\begin{array}{l}\text { Diagnosis } \\
\text { SLE }\end{array}$ & $\begin{array}{l}\geqslant 4 \text { ARA } \\
\text { criteria }\end{array}$ \\
\hline$<10$ & 78 & $35(44 \%)$ & $15(19 \%)$ \\
$10-20$ & 34 & $21(60 \%)$ & 11 & $(31 \%)$ \\
$\geqslant 20$ & 46 & $35(76 \%)$ & $26(56 \%)$ \\
\hline
\end{tabular}

Table 3 Diagnosis of 66 non-SLE sera positive for anti-dsDNA in the IFT

\begin{tabular}{|c|c|c|}
\hline \multirow[t]{2}{*}{ Diagnosis } & \multicolumn{2}{|c|}{ Anti-dsDNA in the Farr assay } \\
\hline & $\begin{array}{l}\text { Neg. }(<10 \\
U / m l)\end{array}$ & $\begin{array}{l}\text { Pos. }(\geqslant 10 \\
U / m l)\end{array}$ \\
\hline Arthritis & 16 & 17 \\
\hline Renal disease & 6 & 0 \\
\hline Liver disease & 5 & $\mathbf{0}$ \\
\hline Drug-induced LE & 4 & 0 \\
\hline Diseases of the respiratory tract & 2 & 0 \\
\hline Disease of the digestive tract & 2 & $\mathbf{0}$ \\
\hline Myasthenia gravis & 1 & $\mathbf{0}$ \\
\hline Dühring's disease & 1 & 0 \\
\hline Hodgkin's disease & 0 & 1 \\
\hline Raynaud's syndrome & 0 & 1 \\
\hline Unknown & 5 & 5 \\
\hline Total & 42 & 24 \\
\hline
\end{tabular}

DIAGNOSIS OF THE ANTI-dSDNA-POSITIVE

NON-SLE PATIENTS

Table 3 shows the clinical diagnosis of the non-SLE patients with a positive kinetoplast/fluorescence. The diagnosis arthritis represents a diversity of diagnoses, mainly RA (21), polysynovitis (1), or arthralgia (10). The same is true for renal disease, representing the following diagnoses, glomerulonephritis (1), focal glomerulonephritis (1), deterioration of the renal function without a pathohistological diagnosis (4); for liver disease, autoimmune hepatitis (1), chronic hepatitis (1), cirrhosis (2), liver carcinoma (1); for diseases of the digestive tract, colitis (1), malabsorption syndrome (1); and for diseases of the respiratory tract, pneumonitis (1),

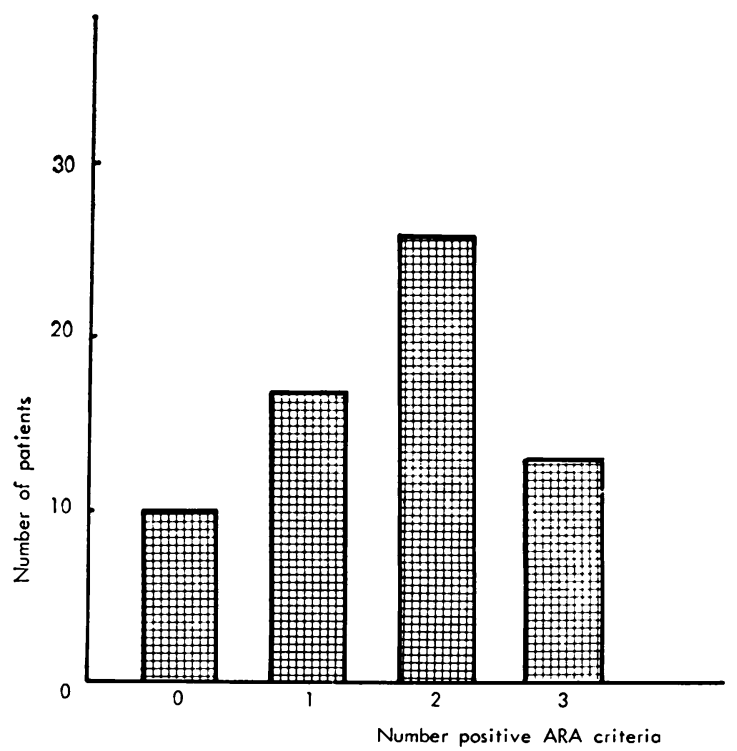

Fig. 2 Frequency of the amount of positive $A R A$ criteria in the 'non-SLE' patients. 
pleuritis (1). Most frequent features of the druginduced LE patients were arthritis (4) in combination with haematological abnormalities (1), pleuritis (1), neurological symptoms (1).

One patient is excluded from Table 3 , because more than 4 ARA criteria were present, but the diagnosis SLE was not made by the clinician. 'Unknown' means that it was impossible for the clinician to make a diagnosis.

When these patients were analysed for their ARA criteria, it was clear that most of them had symptoms strongly related to SLE in that they were positive for several ARA criteria (Fig. 2).

\section{Discussion}

The specificity of antibodies to DNA for SLE has been a subject of considerable debate over the past decade. The main reason for controversy seems to be the use of different assays and, more important, different sources of DNA. The specificity of the test improved when dsDNA was used as antigen and care was taken that the DNA was not contaminated with single-stranded (ss) regions. ${ }^{20-22}$

The indications are that most of the DNA preparations in use for anti-dsDNA determinations are contaminated with ss regions. ${ }^{14}{ }^{23}$. We have shown before that circular dsDNA, isolated from bacteriophage PM2, is free from ss contaminants and does not react with sera with strong anti-ssDNA activity. This experience is shared by others (Maini, personal communication).

A similar specificity was found when sera were tested with the IFT on Crithidia luciliae. Sera containing antibodies to ssDNA did not react with kinetoplasts. ${ }^{12}$ Therefore we feel that only antibodies to dsDNA are detected by these 2 methods. Indeed, when applied to the panel with sera from patients with a defined diagnosis, these assays were very specific for SLE. Antibodies to ssDNA were present in at least 30 non-SLE patients of this panel. This emphasised the critical role of antigen purity.

However, in testing the sera sent to us for routine diagnostic anti-dsDNA determination we completely lost the above described specificity for SLE of our assays. These sera represented a selected material. They came from patients suspected of having SLE. However, these patients were negatively selected for having the actual diagnosis SLE, because a major reason for sending the sera to us was to get further information for the diagnosis.

The finding of anti-dsDNA in non-SLE patients may be clarified by the hypothesis that non-SLE patients with anti-dsDNA will develop SLE. Follow-up studies of anti-dsDNA-positive non-SLE patients revealed that 6 out of 40 patients developed a full SLE picture after entering the study (to be published). Should this explanation prove to be right, it would imply that anti-dsDNA has an important prognostic value. If it is wrong, we are left $\stackrel{\vec{F}}{\rightarrow}$ with the finding that there is a group of patients having anti-dsDNA that do not fulfil the criteria set for $\underline{\underline{O}}$ SLE. It would be interesting to know whether anti- $\frac{\bar{\omega}}{\vec{\alpha}}$ dsDNA in these patients can be differentiated from $\stackrel{\mathbb{\Omega}}{\propto}$ anti-dsDNA found in patients with the diagnosis SLE. That such a difference may exist is indicated $\vec{a}$ by the low correlation found between the IFT and the Farr assay: only 80 of the IFT-positive sera were $\overrightarrow{\vec{\omega}}$ also positive in the Farr assay. In sera of selected SLE patients the correlation between the IFT and the Farr assay was much better. ${ }^{12}$

In that same paper we reported that the Farr assay with PM2 DNA is somewhat more sensitive than the IFT. That would lead one to expect a number of sera to be positive in the Farr assay and negative in the IFT. Because we screen our patients with the IFT, after which only the positive ones are tested in the Farr assay, such a combination does not occur. But how can the high frequency of the reverse combination be explained? We have shown before that the IFT and the Farr assay have differeno sensitivities for different types of antibody owing the variation in antigen presentation in the 2 assays. ${ }^{2}-8$ The IFT seems to detect antibodies with a low avidity better than the Farr assay. This suggests that the non-SLE patients have anti-dsDNA of a somewhat low avidity. Whether this low avidity antidsDNA is related to an early stage of SLE or whether we are dealing with a distinct clinical entity different from SLE remains to be investigated.

\section{References}

1 Stollar B D. The specificity and applications of antibodies to helical nucleic acids. CRC Crit Rev Biochem 1975; 3: 45-69.

2 Rheims M S, Burns R M, Suie T. Intermittent appearance of anti-DNA in the sera of uveitis patients. Am J Opthalmol 1968; 66: 924-8.

3 Pincus T, Schur P H, Rose J A, Decker J L, Talal N. Measurement of serum DNA-binding activity in SLE. $N$ Engl J Med 1969; 281 : 701-5.

4 Epstein W V, Tan M, Eaterbrook M. Serum antibody to double-stranded RNA and DNA in patients with idiopathic and secondary uveitis. $N$ Engl J Med 1971; 285: 1502-6.

5 Hasselbacher P, Leroy E C. Serum DNA-binding activity in healthy subjects on rheumatic disease. Arthritis Rheum 1974; 17: 63-71.

6 Rochmis P G, Palefsky H, Becker M, Roth H, Zvaifler N J. Native DNA binding in rheumatoid arthritis. Ann Rheum Dis 1974; 33: 357-60.

7 Davis P, Atkins B, Hughes G R V. Antibodies to native DNA in discoid lupus erythematosus. $\mathrm{Br} J$ Dermatol 1974; 91 : 175-81.

8 Bell C, Talal N, Schur P. Antibodies to DNA in patients 
with rheumatoid arthritis and juvenile rheumatoid arthritis. Arthritis Rheum 1975; 18: 535-40.

- Jain S, Markham R, Thomas H C, Sherlock S. Double stranded DNA-binding capacity of serum in acute and chronic liver disease. Clin Exp Immunol 1976; 26: 35-41.

10 Grennan D M, Sloane D, Behan A, Carson W D. Clinical significance of antibodies to native DNA as measured by a DNA-binding technique in patients with articular features of rheumatoid arthritis. Ann Rheum Dis 1977; 36: 30-3.

11 Permin H, Halberg P, Christiansen P. Antibodies against double stranded DNA in patients with connective tissue diseases. Acta Med Scand 1978; 203: 61-5.

12 Aarden L A, Lakmaker F, Groot E R de, Swaak A J G, Feltkamp T E W. Detection of antibodies to DNA by radioimmunoassay and immunofluorescence. Scand J Rheumatol 1975; Suppl. 11: 12-9.

13 Holian J, Griffiths I D, Glass D N, Maini R N, Scott J T. Human anti-DNA antibody: Reference standards for diagnosis and management of systemîc lupus erythematosus. Ann Rheum Dis 1975; 34: 438-43.

14 Medof M E, Locker J D, Bennett R M. Antibodies to DNA: False positive results? Arthritis Rheum 1976; 19: 963-4.

15 Lachman P J, Petrie A. Detection of anti-dsDNA as diagnostic tool. Ann Rheum Dis 1977; 36: Suppl. 1, 76-81.

16 Aarden L A. Measurement of anti-dsDNA antibodies. Ann Rheum Dis 1977; Suppl. 36: 91-5.

17 Sontheimer R D, Gillian J N. An immunofluorescence assay for double-stranded DNA antibodies using Crithidia luciliae kinetoplast and double-stranded DNA. $J$ Lab Clin Med 1978; 91: 550-8.

18 Cohen A S, Reynolds W E, Franklin E C, et al. Preliminary criteria for the classification of systemic lupus erythematosus. Bull Rheum Dis 1971; 21 : 643-8.

19 Aarden L A, Groot Els de, Feltkamp T E W. Immunology of DNA. III. Crithidia luciliae, a simple substrate for the determination of anti-dsDNA with the immunofluorescence technique. Trans N Y Acad Sci 1975; 254: 505-15.

20 Aarden L A, Lakmaker F, Feltkamp T E W. Immunology of DNA. I. The influence of reaction conditions on the Farr assay as used for the detection of anti-dsDNA. J Immunol Methods 1976; 10: 27-37.

21 Aarden L A, Lakmaker F, Feltkamp T E W. Immunology of DNA. II. The effect of size and structure of the antigen on the Farr assay. J Immunol Methods 1976; 10: 3948.

22 Aarden L A, Lakmaker F, Groot E R de, Immunology of DNA. IV. Quantitative aspects of the Farr assay. $J$ Immunol Methods 1976; 11: 153-63.

28 Maini R N, Holborow E J (eds.). Detection and measurement of calculating soluble antigen-antibody complexes and anti-DNA antibodies Ann Rheum Dis 1977; Suppl. 1, 36.

24 Aarden L A, Lakmaker F, Groot E de. Immunology of DNA. VI. The effect of mercaptans on IgG and IgM anti-dsDNA. $J$ Immunol Methods 1977; 16: 143-52. 